\title{
Regional Health Information Organization
}

National Cancer Institute

\section{Source}

National Cancer Institute. Regional Health Information Organization. NCI Thesaurus.

Code C156652.

A group of stakeholders in a given geographic region that govern and share healthcarerelated information among them, often electronically, according to accepted healthcare information technology standards. 